\title{
Ponticulus posticus of atlas vertebrae: an incidental finding in Malaysian orthodontic patients
}

\author{
Preethy Mary Donald, ${ }^{1}$ Sumanth Kumbargere Nagraj, ${ }^{1}$ Renjith George Pallivathukkal, ${ }^{2}$ \\ Abdul Rashid Bin Ismail ${ }^{3}$
}

${ }^{1}$ Department of Oral Medicine and Oral Radiology, Faculty of Dentistry,, Melaka-Manipal Medical College, Melaka, Malaysia

${ }^{2}$ Department of Oral Pathology, Faculty of Dentistry, MelakaManipal Medical College, Melaka, Malaysia ${ }^{3}$ Department of Community Dentistry, Faculty of Dentistry, Melaka-Manipal Medical College, Melaka, Malaysia

\section{Correspondence to} Dr Preethy Mary Donald, pmdrsc30@gmail.com

Accepted 20 July 2017

\section{DESCRIPTION}

Ponticulus posticus is a normal anatomical variant of atlas vertebrae (C1) and resides in the posterior arch of atlas in relation to vertebral artery. It is an incidental finding visualised from lateral cephalograms taken for routine orthodontic treatment purpose. Ponticulus posticus in Latin means 'little posterior bridge'. Other synonyms for ponticulus are arcuate foramen, kimerle anomaly, retroarticular foramen and retocondylar foramen. ${ }^{1} \mathrm{An}$ overall incidence of ponticulus posticus has been reported to be $16.7 \%$. Literature reveals a higher incidence in females compared with males and this anomaly was age independent. ${ }^{2}$

This additional bone formation is formed by the calcification of posterior-atlanto occipital membrane. Radiographically, three variations are seen in this normal variant according to Miki et al: a complete form, partial form and calcified form of ponticulus posticus. ${ }^{1}$ The complete form is where the bony ring is fully formed, thus, resembling a foramen. The incomplete form has defects or deficiencies on the bony segment; thus, it does not completely develop into a ring shape. Lastly, the calcified type is merely a linear or amorphous calcification in the same region. It can be either unilateral or bilateral.

This bony bridge is known to contribute to stress related to headaches of chronic type, migraine disorder, dizziness, double vision, stroke, shoulder pain, neck pain or some form of orofacial pain. Maxillofacial surgeons have reported its prime

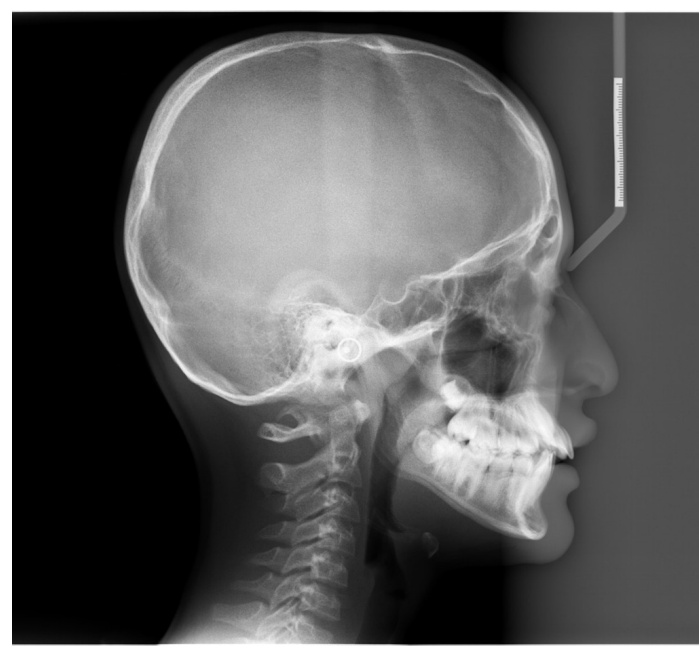

Figure 1 Digital lateral cephalogram of a 13-year-old Malay male child. surgical significance during treatment of atlanto-axial stability for fixation of atlas. During intervention of cervical vertebrae, insertion of surgical screws can cause injury to vertebral artery and suboccipital nerve if the surgeon is not aware of the so-called bony anomaly. This in turn can cause reduced blood circulation and headache in future. Expert surgeons in such cases have recommended to use a modified screw trajectory to avoid piercing the vertebral artery and closely related structures. Casual movements like flexion and extension of neck or continuous trauma in persons with arcuate foramen can compress and restrict movement of vertebral artery. Owing to this, many cases have resulted in stroke especially in children. ${ }^{3}$ The purpose of this case report is to bring awareness of ponticulus posticus among dental academicians and to sensitise orthodontists as the cervical vertebrae can be visualised in routine lateral cephalograms.

\section{CASE REPORT}

We report two cases of ponticulus posticus which was observed as an incidental finding. The first one reported here (figures 1 and 2) is that of a Malay male child aged 13 years. In this case, a radiopaque structure is seen arising from C1 but incompletely formed and has been diagnosed as partial ponticulus posticus. The bony projection originates from superior articulating surface of atlas and terminates short of posterior arch of atlas.

The second case reported here (figures 3 and 4) belongs to a 48 -year-old Chinese female patient. A well-defined radiopacity forming a ring like structure can be appreciated from the radiograph. This

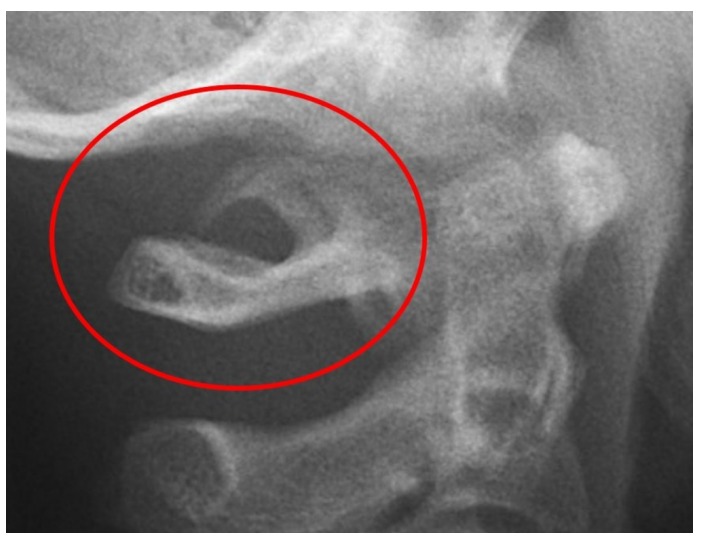

Figure 2 Cropped digital lateral cephalogram of 13-year-old Malay child showing partial ponticulus posticus. 


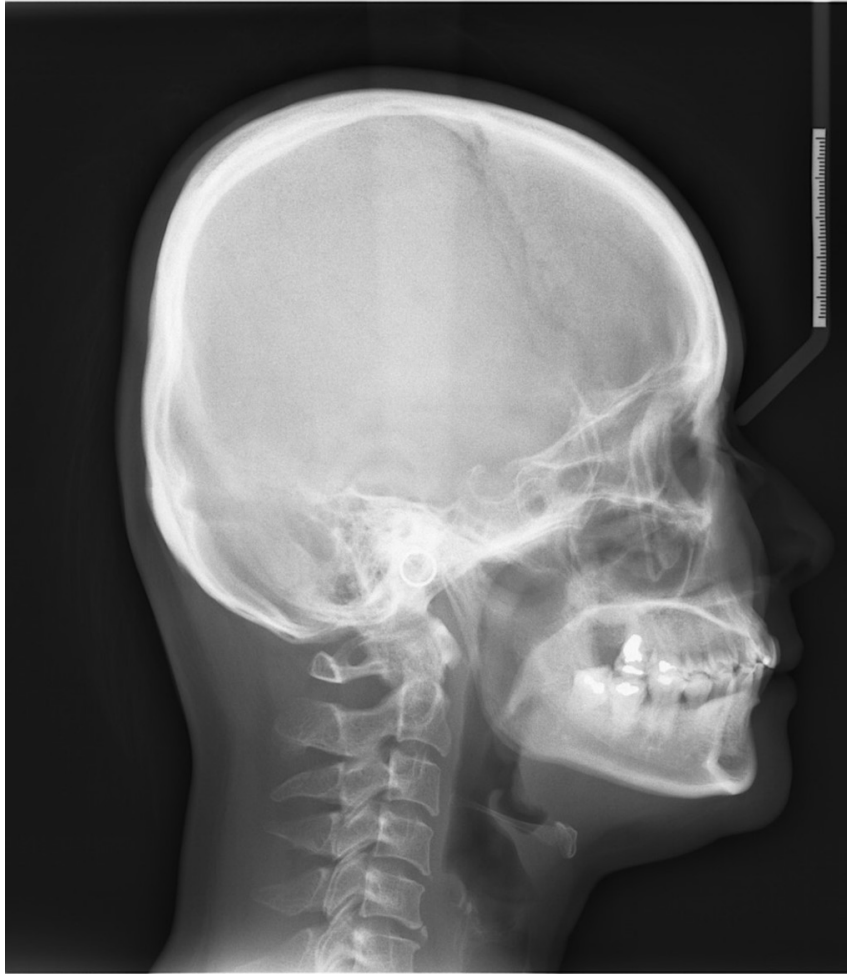

Figure 3 Digital lateral cephalogram of a 42-year-old Chinese female patient.

is diagnosed as complete ponticulus posticus. However, both patients were asymptomatic and did not complain of any headache or related shoulder or neck pain. To understand and identify a patient with ponticulus posticus, a lateral cephalogram of a 35-year-old male patient without any ponticulus posticus anomaly has been shown (figure 5).

As a differential diagnosis related to the cause of dizziness and headaches in the spine region, it is pertinent to consider anomalous origin of vertebral artery as well although such anomalies are rare. ${ }^{4}$ Evidence states that vertebral artery anomalies like kinking, looping and dual origin of vertebral artery attributes to dizziness, migraine headache, occipital headache and cerebrovascular stroke. Hence, if symptomatic, the patient should be referred for screening using advanced imaging modalities like CT angiography and Doppler sonography to rule out the

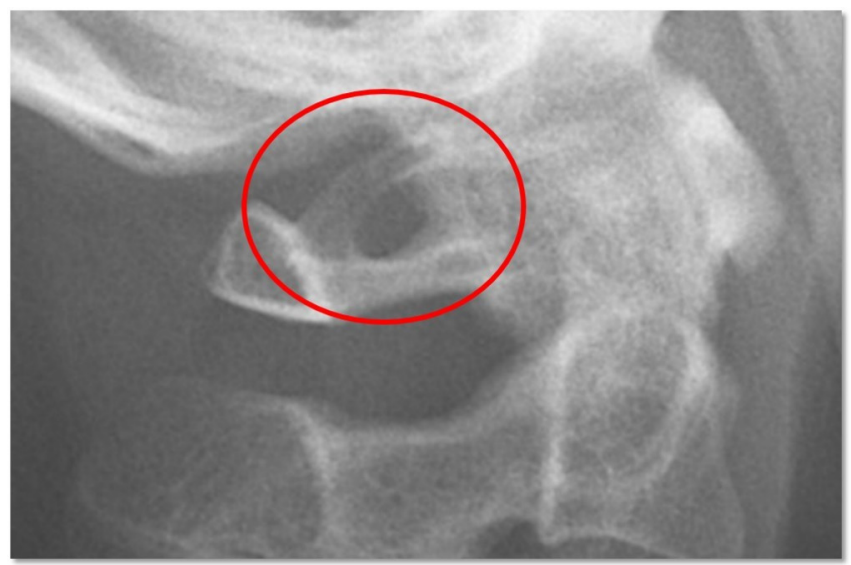

Figure 4 Cropped digital lateral cephalogram of 42-year-old Chinese female patient showing complete ponticulus posticus.

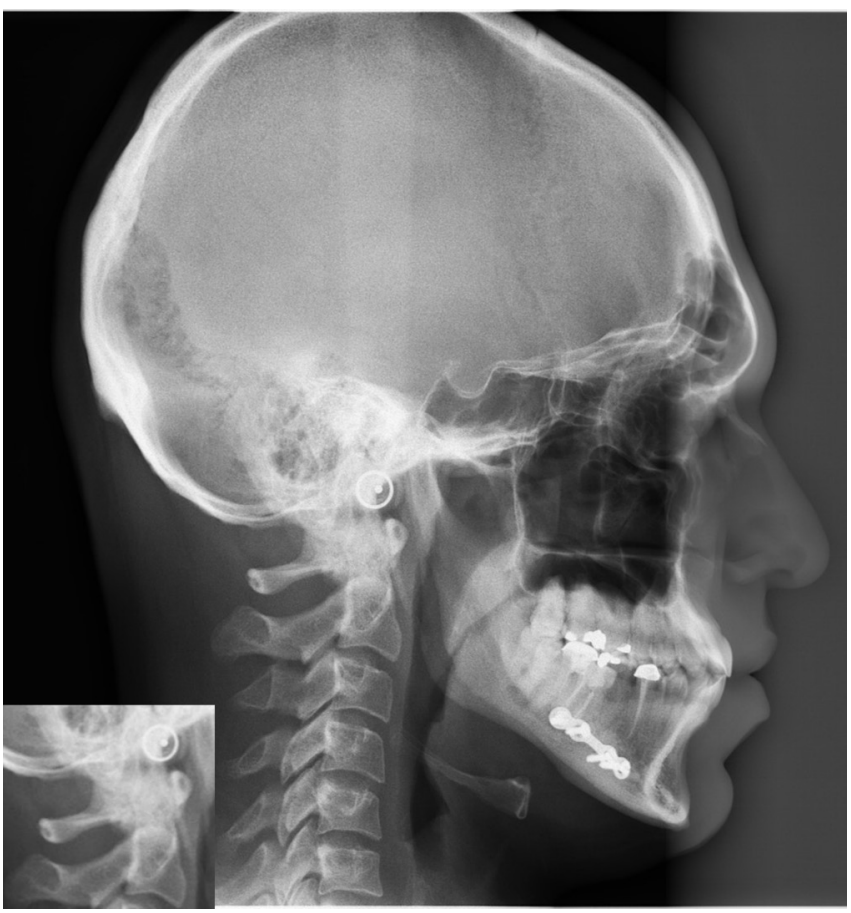

Figure 5 Digital lateral cephalogram of a 35-year-old male patient without ponticulus posticus.

possibility of vertebral artery anomalies. If detected, surgery is the only treatment of choice to improve the circulatory flow and thus aids in relieving headaches. ${ }^{5}$

Dental academicians and private dental practitioners especially orthodontists do have an obligation to inform patients with such anatomic bony anomalies detected on routine lateral cephalograms and its possible related symptoms and complications. Careful assessment of cephalograms and detection of cervical spine bony anomaly can avoid injuries or compression of vertebral artery during its intervention. Further, symptomatic patients should be referred to maxillofacial and endovascular physicians for screening of various vertebral artery anomalies. Awareness of these anomalies is crucial for both maxillofacial surgeons and neurointerventionists during endovascular procedures.

\section{Learning points}

- Functional significance: Ponticulus posticus or arcuate foramen develops in some patients as a means to protect vertebral artery.

- Anatomical significance: Surgeons must be careful while attempting to fix the atlas as this can compress vertebral artery and suboccipital nerve as it passes through this foramen.

- With the presence of foramen, mere traumatic neck movements may contribute to symptoms like headache, migraine, double vision, dizziness or orofacial pain.

- Dentists should inform patients who possess this additional bony defect about its implications and the information can be beneficial for future diagnosis of any head and neck symptoms

- Vertebral artery anomalies are bound to be a predisposing risk factor for headaches and stroke and have to be ruled out. 
Contributors PMD was responsible for the documentation, writing and correspondence of the manuscript. SKN was involved in drafting the article for important intellectual content. RGP did the editing and submission of the manuscript. Proof reading and editing of the manuscript was done by ARBI.

Competing interests None declared.

Patient consent Obtained.

Provenance and peer review Not commissioned; externally peer reviewed.

(c) BMJ Publishing Group Ltd (unless otherwise stated in the text of the article) 2017. All rights reserved. No commercial use is permitted unless otherwise expressly granted.

\section{REFERENCES}

1. Chitroda PK, Katti G, Baba IA, Najmudin M, Ghali SR, Kalmath B, et al. Ponticulus posticus on the posterior arch of atlas, prevalence analysis in symptomatic and asymptomatic patients of gulbarga population. J Clin Diagn Res 2013;7:3044-7.

2 Huang DG, Hao DJ, Fang XY, et al. Ponticulus Posticus. The Spine J 2015;15:17-19.

3 Schilling J, Schilling A, Suazo Galdames I. Ponticulus posticus on the posterior Arch of Atlas, prevalence analysis in asymptomatic patients. Int J Morphol 2010;28:317-22.

4 Malhotra K, Liebeskind DS. Duplicated origin of vertebral artery. Neurol India 2017;65:679-80.

5 Nishijima M, Harada J, Akai T, et al. Operative correction of a kinked duplicate origin of the vertebral artery in a patient with dizziness. Case report. Surg Neurol 1989:32:356-9.

Copyright 2017 BMJ Publishing Group. All rights reserved. For permission to reuse any of this content visit http://group.bmj.com/group/rights-licensing/permissions.

BMJ Case Report Fellows may re-use this article for personal use and teaching without any further permission.

Become a Fellow of BMJ Case Reports today and you can:

- Submit as many cases as you like

- Enjoy fast sympathetic peer review and rapid publication of accepted articles

- Access all the published articles

- Re-use any of the published material for personal use and teaching without further permission

For information on Institutional Fellowships contact consortiasales@bmjgroup.com

Visit casereports.bmj.com for more articles like this and to become a Fellow 